\title{
A SURVEY OF INSECTICIDES RESISTANCE IN POPULATIONS OF Tibraca limbativentris Stal. (HEMIPTERA: PENTATOMIDAE) AN INSECT-PEST OF FLOODED RICE IN BRAZIL
}

\author{
Diogo Nery Maciel ${ }^{1}$; Daniel de Brito Fragoso_2 ${ }_{-}^{2}$ José Alexandre de Freitas Barrigossi² ${ }^{2}$ Mabio Chrisley \\ Lacerda $^{2}$
}

\begin{abstract}
:
The resistance of rice stalk stink bug, Tibraca limbativentris Stal 1860 (Hemiptera: Pentatomidae) to five insecticides was investigated in the present study. The tested insecticides were bifenthrin, carbosulfan, etophenprox, $\lambda$-cyhalothrin, and thiametoxam. The five field-collected populations of rice stalk stink bugs from Luis Alves-GO, Flores de Goiás-GO, Formoso do Araguaia-TO, Lagoa da Confusão-TO and Itajaí-SC were investigated in relation the insecticide resistance occurrence. A further Santo Antônio de Goiás population, from natural environment was used as standard-population of susceptibility. Insects of these populations were submitted to discriminating concentrations (LC95s) with objective to determine the frequences of individuals resistants. The insects population from Formoso do Araguaia were the most resistant to all tested insecticides. The mortality values observed in this population were $76 \%, 86 \%, 72 \%$, $80 \%$, and $80 \%$ for carbosulfan, bifenthrin, etofenprox, $\lambda$-cyhalothrin, and thiamethoxam, respectively. The frequencies of resistant individuals ranged from $9 \%$ a $23 \%$ and were classified as moderate. The more expressive values of the resistance rate (RR) were found to the insecticide thiamethoxan 17-fold in the population of Formoso do Araguaia and 12-fold to the Luís Alves population. This first findings about insecticide resistance in $T$. limbativentris shows the seriousness of the problem in the region and suggests the possible occurrence of cross-selection in this species, confering insecticide resistance to one or more products of different groups. These results are usefuls as information to integrated pest management (IPM) in the regions producers of flooded rice in Brazil, as technical guidance to rice farmers and open news perspectives of investigation in this research area.
\end{abstract}

Keys-Words: Insecta, Pentatomidae, Integrated Pest Management.

\footnotetext{
${ }^{1}$ Master Science Student in Fitossanidade in the Federal University of Goiás - UFG Program.

${ }^{2}$ Researcher of Embrapa Arroz and Feijão Rodovia GO-462. Km 12. Fazenda Capivara. Area Rural Caixa Postal: 179 - CEP:

75375-000 - Santo Antônio from Goiás - GO, daniel.fragoso@embrapa.br
} 


\section{AVALIAÇÃO DA RESISTÊNCIA A INSECTICIDAS EM POPULAÇÕES DE Tibraca limbativentris Stal. (HEMIPTERA: PENTATOMIDAE) UM INSETO-PRAGA DE ARROZ INUNDADO NO BRASIL}

\section{RESUMO:}

A resistência do percevejo do colmo do arroz, Tibraca limbativentris Stal 1860 (Hemiptera: Pentatomidae) a cinco inseticidas foi avaliada no presente estudo. Os inseticidas testados foram bifentrina, carbosulfan, etofenprox, $\lambda$-cialotrina e tiametoxam. As cinco populações de percevejos do colmo do arroz foram coletadas em campo nos municípios de Luis Alves-GO, Flores de Goiás-GO, Formoso do AraguaiaTO, Lagoa da Confusão-TO e Itajaí-SC. As amostras foram avaliadas em relação à a resistência à inseticidas. Outra população de Santo Antônio de Goiás, de ambiente natural, foi utilizada como populaçãopadrão de suscetibilidade. Os insetos dessas populações foram submetidos a concentrações discriminantes (CL95s) com o objetivo de determinar as frequências de indivíduos resistentes. A população de insetos de Formoso do Araguaia foi a mais resistente a todos os inseticidas testados. Os valores de mortalidade observados nesta população foram $76 \%, 86 \%, 72 \%, 80 \%$ e $80 \%$ para carbosulfan, bifentrina, etofenprox, $\lambda$ cialotrina e tiametoxame, respectivamente. As frequências de indivíduos resistentes variaram de $9 \%$ a $23 \%$ e foram classificadas como moderadas. Os valores mais expressivos da taxa de resistência (RR) foram encontrados no inseticida tiametoxan 17 vezes na população de Formoso do Araguaia e 12 vezes na população de Luís Alves. Este primeiro relato sobre resistência a inseticidas em T. limbativentris mostra a gravidade do problema na região e sugere a possível ocorrência de seleção cruzada nesta espécie, conferindo resistência inseticida a um ou mais produtos de diferentes grupos. Esses resultados são úteis como informações para o manejo integrado de pragas (MIP) nas regiões produtoras de arroz irrigado no Brasil, como orientação técnica aos rizicultores e abre novas perspectivas de investigação nesta área de pesquisa.

Palavras-chave: Insecta, Pentatomidae, Manejo Integrado de Pragas. 


\section{INTRODUCTION}

The rice stalk stink bug Tibraca limbativentris Stal $1860 \quad$ (Hemiptera: Pentatomidae) is considered an important pest of rice in the South America (Pantoja et al., 2007). In Brazil, on favorable climatic conditions, high infestations can occur in all regions that produce flooded rice, reducing the production in up to $80 \%$ (Ferreira et al., 1997).

In the field, nymphs and adults of stalk stink bug starts to feed of rice plants from 20 days after germination of the seeds. The insect-pest introduce its stylet at the base of stem the rice plant, sucks the sap and cause an injury recognized as "dead-heart" (Ferreira et al., 1997).

The use of insecticides for the control of insect-pests in rice in Brazil is growing. According to the National Union of the Industry of Products for Agricultural Defense (Sindiveg, 2017), 804 tons of insecticides were sold to the control of insect-pests of rice in 2012 . The expressive use of insecticides in the plantation of flooded rice in Brazil has negative effects on the integrated pest management (IPM), including the elimination of natural enemies, insect-pests resurgence and development of insecticide resistance.

Insecticide use have been the principal method of control used against $T$. limbativentris in Brazil (Barrigossi et. al., 2004), although there have been are efforts to use of other methods, as a biological control (Martins et al., 2004; Quintela et al., 2013). In Brazil, the registered products to be used against $T$. limbativentris include pyrethroids (bifenthrin, $\quad$ etofenproxi, $\lambda$-cyhalothrin), neonecotinoids (thiamethoxam) and carbamates (carbosulfan). The use of commercial formulation of insecticide mixtures associating pyretroids with other insecticides group is very commom practice aiming to increse the efficiency of the insecticides in the control of $T$. limbativentris.

Resistance to insecticides has growing significantly in the agriculture field and this constitutes a great challenge for the insect-pests control in current days (Sparks and Nauen, 2015). Since first the register of insect resistant to insecticides, occurred in 1914 (Melander, 1914), the number of cases reached 586 species of insects and resistant mites to 325 composed (Sparks and Nauen, 2015). The negative consequences of insecticide resistance are need of to increase the dosage of the product and in the number of applications, in some cases the substitution for products of higher toxicity (Whalon et al., 2008).

In this context, the studies of detection and monitoring of insect-pest insecticide resistance are important and concern all team involved with the applied control and implementation of effective program of management resistance insecticides (MRI).

In flooded rice some species have developed insecticide resistance, for example stalk borers, Chilo suppressalis that have presented resistance to various insecticides (Su et al., 2014). Studies exploring insecticide resistance in $T$. limbativentris are incipients, fact that motived us to carry this investigation.

The present study was carried out to detect insecticide resistance in rice stalk stink bugs collected from important rice flooded areas in Brazil and provide information to management resistance insecticide (MRI).

\section{MATERIAL AND METHODS}

\section{INSECTS}

Five populations of $T$. limbativentris from the major rice flooded areas: Goiás, Santa Catarina, and Tocantins state were used in this study (Fig. 1). These populations were collected in rice fields and were maintained in cages in a greenhouse, starting with at least 100 individuals. Each cage consisted of a pott with rice plants (BR Irga 409) covered with a nylon cloth. To prevent any possible alteration in the genetic composition, all populations were maintained without insecticide application. 
A further population was collected from native vegetation in this paper named CNPAF. It National Research Center for Rice and Beans in was used as susceptible standard population.

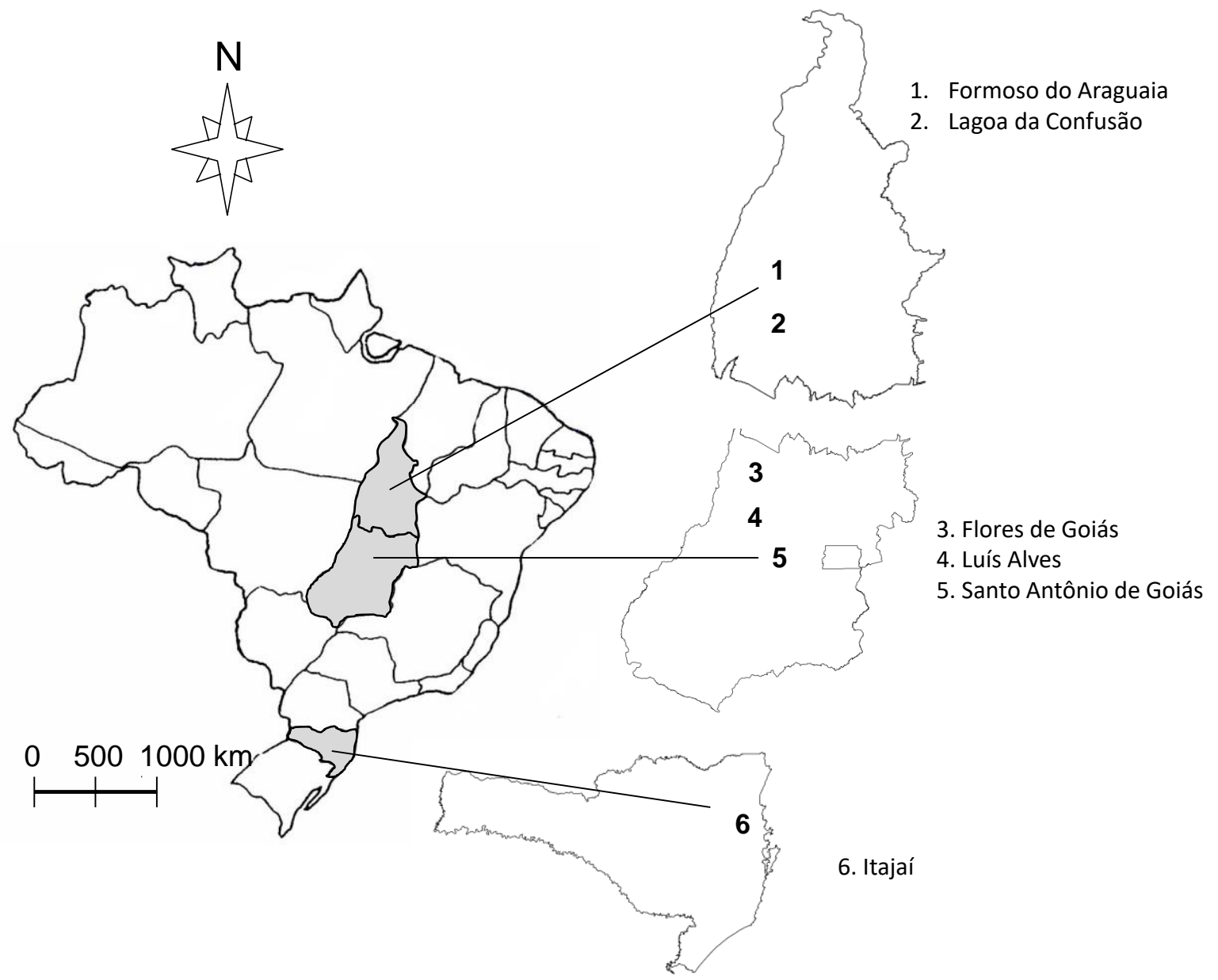

Figure 1- Origin of the collection sites of the Tibraca limbativentris population.

\section{INSECTICIDES}

Five insecticides: bifenthrin (98,0\% pure), carbosulfan $(97,1 \%$ pure $)$, etofenprox $(98,5 \%$ pure), $\lambda$-cyhalothrin $(98,0 \%$ pure $)$ and thiamethoxan $(95,0 \%$ pure $)$ with high level of analyitical purity purchased from Sigma-Aldrich were used in the bioassays (Table 1). Insecticide concentrations were prepared using analytical quality acetone $(99,5 \%$ pure) purchased from ISOFAR Ind., as solvent.

Table 1 - Registered insecticides used against T. limbativentris in flooded rice, in Brazil. 


\begin{tabular}{|c|c|c|c|c|}
\hline \multirow{2}{*}{ Insecticide } & \multirow{2}{*}{ Chemical group } & \multicolumn{2}{|c|}{ Classification } & \multirow{2}{*}{ Mode of Action (MoA) } \\
\hline & & Toxicological & Environmental & \\
\hline Bifenthrin & Pyrethroids & III & II & $\begin{array}{l}\text { Sodium channel } \\
\text { modulators }\end{array}$ \\
\hline Carbosulfan & Carbamates & II & I & $\begin{array}{l}\text { Acetylcholinesterase } \\
\text { (AChE) inhibitors }\end{array}$ \\
\hline Etofenprox & Pyrethroids & III & III & $\begin{array}{c}\text { Sodium channel } \\
\text { modulators }\end{array}$ \\
\hline$\lambda$-cyhalothrin & Pyrethroids & III & I & $\begin{array}{c}\text { Sodium channel } \\
\text { modulators }\end{array}$ \\
\hline Thiamethoxam & Neonicotinoids & III & III & $\begin{array}{l}\text { Nicotinic acetylcholine } \\
\text { receptor (nAChR) }\end{array}$ \\
\hline
\end{tabular}

A concentration-mortality bioassay for each insecticide was carried out to evaluate the residual insecticide activity on $T$. limbativentris. The experimental design was completely randomized, with five replication. Transparent cylindrical glassvials of $20 \mathrm{~mL}$ capacity were used to evaluate residual insecticide impregnated in internal walls (Nieltsen et al., 2008). Five graduated doses for each insecticide (1mg.mL ${ }^{-1}, 10^{-1} \mathrm{mg} \cdot \mathrm{mL}^{-1}, 10$ ${ }^{2} \mathrm{mg} \cdot \mathrm{mL}^{-1}, 10^{-3} \mathrm{mg} \cdot \mathrm{mL}^{-1}, 10^{-4} \mathrm{mg} \cdot \mathrm{mL}^{-1}, 10^{-5} \mathrm{mg} \cdot \mathrm{mL}^{-}$ $\left.{ }^{1}\right)$ were assayed in the preliminary bioassays. The glass-vial was prepared by pipetting $0,5 \mathrm{~mL}$ of insecticide and acetone solution into each vial. Vials treated with acetone was used as control. Vials were gently rolled until acetone had completely evaporated to ensure that insecticide had evenly spread to the inner glass-vial wall. .Two adult non-sexed stink bugs of the same age (one to five days old) were placed into each treated vial and kept under laboratoy condition $\left(25-26{ }^{\circ} \mathrm{C}\right)$. Mortality and morbity was evaluated 24 hours after insecticide exposure. Stink bugs were considered dead if unable to walk when prodded with a fine hair brush (Fragoso et al., 2003).

After determining the appropriated interval of concentrations to kill T. limativentris a second concentration-mortality insecticide bioassays was carried out to establish the dose-response curve for each insecticide. In these bioassays, the experimental design was the same used in the preliminary bioassays. For those populations where resistance was detected in preliminary bioassays, other concentration-mortality curves were established for each insecticide. The rate of resistance (RR) was determined dividing $\mathrm{CL}_{50}$ of the resistant population by $\mathrm{CL}_{50}$ of the standard susceptible population.

The International Resistance Action Committee approves the method of impregnation of the dry residue of insecticides used in the present work to evaluate the susceptibility of populations of $\mathrm{T}$. limbativentris to the insecticides IRAC and used for basic studies of detection and monitoring resistance of insects to insecticides in piercing sucking insects (IRAC, 2021).

\section{DATA ANALYSIS}

Concentration-mortality data were subjected to probit analysis (PROC PROBIT; SAS Institute, 2010). The resistant populations were identified in the bioassays for resistance detection with a CL95 of the standard susceptible population (CNPAF) using unilateral $\mathrm{Z}$ test at $95 \%$ confidence with correction for continuity (Roush and Miller,1986).

\section{RESULTS AND DISCUSSION}

The concentration mortality curves for the standard susceptible population of $T$. limbativentris exposed to the insecticides bifenthrin, carbosulfan, 
etofenprox, $\lambda$-cyhalothrin and thiamethoxam are presented in Table 2.

Table 2 - Toxicity of insecticides against a standard susceptible population of T. limbativentris.

\begin{tabular}{ccccccc}
\hline Inseticide & $\mathbf{N}$ & $\begin{array}{c}\text { Slope } \\
\mathbf{\pm S E M}\end{array}$ & $\begin{array}{c}\text { CL50 }(\mathbf{I C ~ 9 5 \% )} \\
\boldsymbol{\mu g} \mathbf{i . a . c m}\end{array}$ & $\begin{array}{c}\text { CL95 }(\mathbf{I C ~ 9 5 \% )} \\
\boldsymbol{\mu g} \mathbf{i . a . c m}\end{array}$ & $\boldsymbol{X}^{\mathbf{2}}$ & Prob. \\
\hline Bifenthrin & 50 & $0,98 \pm 0,12$ & $0,02(0,01-0,03)$ & $0,05(0,03-0,17)$ & 13,79 & 0,74 \\
Carbosulfan & 50 & $0,71 \pm 0,12$ & $0,34(0,23-0,55)$ & $2,01(1,05-4,55)$ & 30,31 & 0,34 \\
Etofenprox & 50 & $0,80 \pm 0,11$ & $0,40(0,26-0,96)$ & $1,21(0,11-4,46)$ & 17,61 & 0,54 \\
$\lambda$-cialothrin & 50 & $0,83 \pm 0,21$ & $0,07(0,03-0,17)$ & $0,21(0,08-3,50)$ & 9,44 & 0,80 \\
Tiamethoxam & 50 & $0,72 \pm 0,15$ & $0,02(0,01-0,003)$ & $0,17(0,09-0,63)$ & 3,32 & 0,34 \\
\hline
\end{tabular}

$\mathrm{N}=$ Number of insects used in the test; SEM = Standard Error of Media; CL = Lethal Concentration; IC = Confidence Interval; $\chi^{2}=$ Qui-square.

Table 3 - Control corrected mortality of field-collected populations of T. limbativentris at discriminating concentrations.

\begin{tabular}{lccccc}
\hline \multirow{2}{*}{ Population } & \multicolumn{5}{c}{ Mortality (\%) } \\
\cline { 2 - 6 } & Bifenthrin & Carbossulfan & Etofenprox & $\lambda$-cialotrina & Tiamethoxam \\
\hline Flores de Goiás & 97 & 100 & 92 & 95 & 97 \\
Formoso do Araguaia & $86^{*}$ & $76^{*}$ & $72^{*}$ & $80^{*}$ & $80^{*}$ \\
Itajaí & 97 & 100 & 95 & 95 & 100 \\
Lagoa da Confusão & 95 & 100 & 95 & 95 & $90^{*}$ \\
Luís Alves & 95 & 96 & $85^{*}$ & 95 & $82^{*}$ \\
Santo Antônio de Goiás & 96 & 95 & 98 & 94 & 95 \\
\hline
\end{tabular}

*Mortalities followed by an asterisk are significantly different from mortalities observed in the standard susceptible population by the 1 -sided $\mathrm{Z}$ test at $95 \% \mathrm{CL}$ with correction for continuity. 
Table 4. Toxicity of insecticides against resistant populations of $T$. limbativentris in relation the standard susceptible population.

\begin{tabular}{|c|c|c|c|c|c|c|c|c|}
\hline Insecticide & Population & $\mathbf{N}$ & $\begin{array}{l}\text { Slope } \\
\pm \text { SEM }\end{array}$ & $\begin{array}{c}\text { CL50 (IC 95\%) } \\
\mu \text { g i.a.cm- }{ }^{2}\end{array}$ & $\begin{array}{c}\text { CL95 (IC 95\%) } \\
\mu \text { i.a.cm- }\end{array}$ & $\mathbf{R R}$ & $\chi^{2}$ & $\mathbf{P}>\chi^{2}$ \\
\hline \multirow{2}{*}{ Bifenthrin } & Santo Antônio de Goiás & 50 & $0,98 \pm 0,12$ & $0,02(0,01-0,03)$ & $0,05(0,03-0,17)$ & -- & 13,79 & 0,74 \\
\hline & Luís Alves & 50 & $0,66 \pm 0,13$ & $0,04(0,02-0,06)$ & $0,09(0,04-0,38)$ & 2,0 & 21,56 & 0.55 \\
\hline \multirow{2}{*}{ Carbosulfan } & Santo Antonio de Goiás & 50 & $0,71 \pm 0,12$ & $0.34(0,23-0,55)$ & $2,01(1,05-4,55)$ & -- & 30,31 & 0,34 \\
\hline & Luís Alves & 50 & $0,66 \pm 0,13$ & $0,38(0,12-1,28)$ & $2,86(1,25-6,25)$ & 1,1 & 21,56 & 0,55 \\
\hline \multirow{3}{*}{ Etofenprox } & Santo Antônio de Goiás & 50 & $0,80 \pm 0,11$ & $0,40(0,26-0,96)$ & $1,21(0,11-4,46)$ & -- & 17,61 & 0,54 \\
\hline & Formoso do Araguaia & 50 & $0,82 \pm 0,20$ & $1,21(0,96-1,34)$ & $1,84(1,50-3,88)$ & 3,0 & 12,96 & 0,67 \\
\hline & Luís Alves & 50 & $1,27 \pm 0,31$ & $0,71(0,46-1,06)$ & $1,73(1,15-4,78)$ & 1,7 & 17,79 & 0,33 \\
\hline \multirow{3}{*}{ Tiamethoxam } & Santo Antônio de Goiás & 50 & $0,72 \pm 0,15$ & $0,02(0,01-0,003)$ & $0,17(0,09-0,63)$ & -- & 3,32 & 0,34 \\
\hline & Formoso do Araguaia & 50 & $0,70 \pm 0,07$ & $0,32(0,15-0,50)$ & $1,53(0,92-5,57)$ & 17 & 0,84 & 0,83 \\
\hline & Luís Alves & 50 & $0,59 \pm 0,10$ & $0,23(0,07-0,38)$ & $1,34(0,76-5,76)$ & 12 & 1,08 & 0,78 \\
\hline
\end{tabular}

$\mathrm{N}=$ number of insects used in the bioensaios of concentration mortality; EP = I miss pattern of the average; CL = Lethal Concentration; RR = resistance Reason. obtained by the division of the value of CL50 of each resistant population by the value of CL50 of the susceptible population; IC = trust interval; $\chi^{2}=$ Chi-square. 
In this study was possible the recognize the resistant populations of rice stalk stink bug $T$. limbativentris to the main products used for control in areas of flooded rice in Brazil. In Formoso do Araguaia the situation appears particularly serious where was observed frequencies of resistant individuals to all tested insecticides: bifenthrin, carbosulfan, etofenprox. $\lambda$-cyhalothrin, and tiamethoxam (Table 4). The population from Luis Alves showed resistance to etofenprox and thiamethoxam. The individuals' mortality of $T$. limbativentris in the population of Formoso do Araguaia was $86 \%$ for bifenthrin, $76 \%$ for carbosulfan, $72 \%$ for etofenprox and $80 \%$ for insecticide tiamethoxam. The individuals' mortality in the population collected from Luis Alves was $85 \%$ for etofenprox and $82 \%$ for thiametoxam.

Pesticide resistance within the order Arthropoda has been a subject of interest among pest management professionals since the first case was registered in 1914, in the San Jose scale Quadraspidiotus perniciosus (Comstock). The scientific community believes that pesticide resistance is one of the main problems facing crop protection, animal production and human health (Whalon, 2008; Holomom, 2012). In agriculture, this is the most serious and global problem affecting integrated pest management (Spark and Nauem, 2015). The Internation Insecticide Resistance Action Committee (IRAC) consider insecticide resistance (IR) as a global problem and need a global response for the effective management (IRAC, 2017).

The effective management program of insecticide resistance needs tobe made with the adoption of various strategies integrated, including the rotation of ingredient actives with different mode of action as principal primary tool (Holomom, 2012; Tabashnik et al.. 2013). Based on our findings, to Formoso do Araguaia population, the rotation strategy is committed, considering the seriousness of the problem where the insects from this region became resistant to all insecticides used in its control and the existence of few products registered for the control this pest in flooded rice in Brazil.

In this case, management strategies can be: reduction of the selection pressure to these insecticides that presented problem of resistance, the implemmentation of integrated pest management (IPM) with the use of biological control agents to minimize the problem and to reduce the use of chemical control. And finally, the register of new products with different mode of action to be used in rotation.

The selection pressure by insecticide reduces the genetic variability of the species, selecting individuals most adapted to the biotic and abiotic factors of the environment in which they are inserted. A study carried out on the genetic diversity of $T$. limbativentris shows that, although there is high similarity between some populations of this species, there isn't overlap between them, this indicating that each population tends to be unique and tends to occur the genetic isolation (Rampelloti et al., 2008).

So, considering that there is a long geographic distance between the flooded rice in Brazil and low migration of insects adults associated with the behavior of hibernation in the absence of food during a year period (may-oct), the population of rice stalk stink bugs can suffer a process of genetic isolation and selection by the insecticide.

Therefore, if there is no adoption of an integrated pest management (IPM) program, we can have more severe problems controlling this insect pest in flooded rice in Brazil in the future. This is true because the active ingredients registered for the control of $T$. limbativenris are only three: carbossulfan - an inhibitor of the enzyme acetilcolinesterase; lambda-cialotrina - a modulator of the sodium channels of and tiametoxan - nicotinic acetylcholine receptor $(\mathrm{nAChR})$ and that rice stalk stink bug presents behavior of genetic. the problem can be in the future more serious for control of this important insect-pest in flooded rice in Brazil. 
The population of $T$. limbativentris from National Centre of Research of Rice and Bean (Santo Antônio de Goiás) presented smaller values of $\mathrm{CL}_{50}$ for all tested insecticides and allowed to compare and recognition populations of $T$. limbativentris resistants and it can be used as a standard of susceptibility in the study.

The resistance rate $(\mathrm{RR})$ values varying from 2.5 to 17.0 and from 2.0 to 12.0 to the populations of Formoso do Araguaia and Luís Alves - GO, respectively. In terms of magnitude, it can be characterized as moderate levels of resistance, since it already has alert signals . In order to evaluate it is necessary to continue to monitor its evolution.

The results on insecticide resistance in populations of $T$. limbativentris obtained in this study are important for the selection and adoption of insecticide resistance management strategies (IRM).It is relevant as it can guide producers to reduce the pressure of the use of insecticides in these localities locations and to rotate active ingredients, mainly relatated to the insecticide thiamethoxam. This would prevent or delay the development of populations highly resistant to the analyzed products. We will use the obtained information for technical guidance on the use of chemical control and insecticide resistance management (IRM) in populations of the rice stalk stink bug, considered to be one of the most important insect pests of flooded rice in Brazil.

\section{CONCLUSIONS}

Our study provided the first baseline data on the status of insecticide resistance status in $T$. limbativentris populations of important rice producing regions in Brazil. These findings are useful to the selection and adoption of the strategies recommended for insecticide resistance management (IRM).

\section{ACKNOWLEDGEMENTS}

We thank the entomology team of Embrapa Rice and Bean for the valuable help with the maintenance of rice stalk stink bug populations. Special thanks to the National Council of Scientific and Technological Development - CNPq (Project 562621/2010-5) and Embrapa (SEG 02.11.05.009.00.00).

\section{REFERENCES}

Barrigossi, J.A.F.; Lanna, A.C.; Ferreira, E. (2004). Agrotóxicos no Cultivo do Arroz no Brasil: análise do consumo e medidas para reduzir o impacto ambiental negativo. Santo Antônio de Goiás: Embrapa Arroz e Feijão. 8p.

Ferreira, E.; Zimmermann, F. J. D.; Santos, A.B.; Neves, B.P. (1997). O percevejo do colmo na cultura do arroz. Goiânia. EMBRAPA - Arroz e Feijão. 43p.

Fragoso, D. de B.; Guedes, R.N.C.; Resende, S. T. (2003). Glutathione S-transferase detosification as a potential pyrethroid resistance mechanism in the weevil, Sithophilus zeamais. Entomologia Experimentalis et Applicata109: 21-29. https://doi.org/10.1046/j.1570-7458.2003.00085.x

Hollomon, D.W. (2012). Do we have the tools to manage resistance in the future? Pest Management Science 68: 149-154. https://doi.org/10.1002/ps.2291

IRAC - International Resistance Action Commmittee. (2021). Test methods. Disponível em: http://www.irac-online.org/methods/.

Martins, J.F. da S.; Botton, M.; Carbonari, J.J.; Quintela, E.D. (2004). Eficiência de Metarhizium anisopliae no controle do percevejo-do-colmo Tibraca limbativentris (Heteroptera: Pentatomidae) em lavoura de arroz irrigado. Ciência Rural 34(6): 1681-1688.

Melander, A.L. (1914). Can insects become resistant to sprays? Journal of Economic Entomology 7(2):167-173.

https://doi.org/10.1093/jee/7.2.167 
Nielsen, A.L; Shearer, P.W; Hamilton, G. (2008). Toxicity of insecticides to Halyomorpha halys (Hemiptera: Pentatomidae) using glass-vial bioassays. Journal of Economic Entomology 101(4): $\quad 439-1442$. DOI: $10.1603 / 0022-$ 0493(2008)101[1439:toithh]2.0.co;2

Pantoja, A.; Triana, Monica.; Bastidas, H.; Garcia, C.; Mejia, O.I.; Duque, M.C. (2007). Damage by Tibraca limbativentris(Hemiptera: Pentatomidae) to rice in Southwestern Colombia. Journal of Agriculture of the University of Puerto Rico 91(1-2):11-18 https://doi.org/10.46429/jaupr.v91i1-2.2649

Quintela, E.D.; Mascarin, G.M.; Silva, R.A.; Barrigossi, J.A.F.; Martins, J.F.S. (2013). Enhanced susceptibility of Tibraca limbativentris (Heteroptera: Pentatomidae) to Metarhizium anisopliae with sublethal doses of chemical insecticides. Biological Control 66: 56-64. https://doi.org/10.1016/j.biocontrol.2013.03.018

Rampelotti, F.T.; Ferreira, A.; Tcacenco, F.A.; Martins, J.F.S; Grützmacher, A.D; Prando, H.F. (2008). Diversidade Genética de Tibraca limbativentris Stål (Hemiptera: Pentatomidae) de Santa Catarina e do Rio Grande do Sul. Usando Marcadores RAPD. Neotropical Entomology 37(1): 020-029. https://doi.org/10.1590/S1519566X2008000100004.

Roush, R.T.; Miller, G.L. (1986). Considerations for design of insecticide resistance monitoring programs. Journal of Econ. Entomology 79: 293298. https://doi.org/10.1093/jee/79.2.293

SAS Institute. (2010). SAS/STAT user's guide. version 6. Cary . NC. USA. SAS Institute.

Sparks, T.C. (2013). Insecticide discovery: an evaluation and analysis. Pesticide Biochemical and Physiology 107: 8-17. DOI: 10.1016/j.pestbp.2013.05.012

Sparks, T.C.; Nauen, R. (2015). IRAC: Mode of action classification and insecticide resistance management. Pesticide Biochemistry and Physiology. 121:122-128. https://doi.org/10.1016/j.pestbp.2014.11.014

SINDIVEG - Sindicato Nacional da Indústria de Produtos para Defesa Vegetal. (2017). Vendas por Cultura - 2010 a 2012. Disponvel em: http://dados.contraosagrotoxicos.org/dataset/comer cializacao-sindag/resource/abc56438-408e-4ca6b898-ce4d7b392dd3?inner_span=True.

Su, J.; Zhang, Z.; Wu, M.; Gao, G. (2014). Changes in Insecticide Resistance of the Rice Striped Stem Borer (Lepidoptera: Crambidae). Journal of Economic Entomology 107(1): 333-341. https://doi.org/10.1603/EC13285

Tabashnik, B.E.; Brévault, T.; Carrière, Y. (2013). Insect resistance to Bt crops: lessons from the first billion acres. Nature Biotechnology 31: 510-521. doi:10.1038/nbt.2597

Tabashnik, B.E.; Mota-Sanchez, D.; Whalon, M.E.; Hollingworth, R.M.; Carrière, Y. (2014). Defining terms for proactive management of resistance to $\mathrm{Bt}$ crops and pesticides. Journal of Economic Entomology 107: 496-507. https://doi.org/10.1603/EC13458

Whalon, M.E.; Mota-Sanchez, D.; Hollingworth, R.M. (2008). Analysis of global pesticide resistance in arthropods. In: Whalon, M.E.; MotaSanchez, D.; Hollingworth, R.M. (eds.). Global pesticide resistance in arthropods. Cambridge. CAB International. p. 5-31. 